\title{
CAUSALITY BETWEEN EXPORTS AND ECONOMIC GROWTH: EMPIRICAL ESTIMATES FOR SLOVENIA
}

\author{
Jani BEKŐ*
}

\begin{abstract}
:
This paper employs error-correction representation approach and conditional causality technique to assess the patterns of export-economic growth link in Slovenia. In general, the results support the existence of bi-directional causality between export variables and indicators of domestic economic activity. The evidenced bi-directional causality of exportoutput relation for Slovenia suggests that any characterization of a small country's growth as export-driven may be at least perfunctory. As the results imply, there are no trade-offs between whether to pursue a growth strategy of structural reforms for internal competitiveness with the goal of higher domestic growth and afterwards an increasing exports, or to apply trade policy for improving the international competitiveness and enabling the economy a quick response to foreign demand.
\end{abstract}

Keywords: exports, economic growth and causality

JEL Classification: C40, F43

\section{Introduction}

Rapid re-orientation of domestic production capacities from the former common Yugoslav market towards international markets after mid-1991, as one of the factors markedly shaping the structure of domestic export supply, resulted in the increasing inclusion of Slovenia into the global economy. Such large-scale and, above all, quick integration inevitably raises the question about the empirical nature of export-output nexus. The way how export flows and economic growth are connected has been investigated in a large number of studies using a wide range of different empirical techniques (see Afxentiou, Serletis, 1991; Marin, 1992; Greenaway, Sapsford, 1994; Ahmad, Harnhirun, 1995; Pomponio, 1996; Riezman et al., 1996; the latest comprehensive survey can be found in Giles, Williams, 2000a, 2000b), however, none of them have intensively dealt with an individual country in transiti-

*) Faculty of Economics and Business, University of Maribor, Razlagova 14, 2001 Maribor, Slovenia (e-mail: jani.beko@uni-mb.si).

${ }^{\star *}$ ) The author would like to thank Velimir Bole, András Inotai and an anonymous referees for their comments on previous drafts. 
on. The present article attempts to fill this gap by focusing exclusively on the Slovenian economy.

The theoretical literature usually offers three different expositions for the causal nexus of exports and output. According to the export propelled growth hypothesis, analogously with investment in the closed economy model, exports represent the autonomous component of demand in the orthodox Keynesian theory of export-led growth (see Beckerman, 1962; McCombie, Thirlwall, 1994). The theory advocates the following growth circle: foreign demand $\Rightarrow$ acceleration of investment activity $\Rightarrow$ domestic production $\Rightarrow$ increasing returns to scale $\Rightarrow$ growth of exports $\Rightarrow$ growth of output. In comparison with the export-led growth models, the technology theories, product and profit cycle theories (see Vernon, 1966; Hirsch, 1967; Markusen, 1985) propose a causal link, which runs from domestic activity to exports rather than vice versa. Sharp competition in the export markets in these models is attributed to market power established through innovation and development of new products. While product cycle theory and its model re-formulations suggest a one-way growth link between real output and exports, the third group of theories - the new international trade theory (see Krugman, 1979; Krugman, 1980), relying on regularities of intra-industry trade, expects a two-way causality. The theory incorporating imperfect competition, economies of scale and product differentiation argues that economies of agglomeration and concentration provide large scale gains, whereas an increase in productivity enables the development of new technologies. The latter then leads to pronounced product differentiation and through realization of economies of scale, to new productivity gains, and finally, to enlargement of exports.

It is important to emphasize that the Slovenian economy and its foreign trade are marked with two special characteristics, which do not necessarily follow the logic and conclusions deducted from the presented theoretical elucidations of exportoutput link, regularly applied to developed market economies. First, rapid and mainly successful re-orientation of foreign trade accompanied by partly pronounced structural upgrading has been executed on the basis of "training ground theory" in Slovenia (as well as in other transition countries). The development pattern of foreign trade in transition economies therefore did not follow the Latin American way (from national over regional import substitution towards only hardly, if at all, achieved global competitiveness) but was more similar to the East Asian model of swift opening, which induced mechanisms for the invigoration of the country's external competitiveness. The second characteristics involves the growth of transition countries that is predominantly grounded on the activities of transnational corporations and only to a lesser extent on activities of small and medium-sized companies. Although on this feature in also frequently grounded the mutual interlacement of exports and home production in developed economies, the introduced growth pattern seems to gain little importance in Slovenian case. Comparison of Slovenia with developed market economies and the most successful transition economies namely shows that the significance of foreign direct investment (FDI), as a key mechanism of domestic enterprise sector for the creation of strategic trade alliances with foreign companies, in the Slovenian economy is quite small in terms of the FDI inflow to GDP ratio (see e.g. Mrak et al., 2002).

In addition, there are, at least from the economic growth point of view, two reasons for why it is important to detect the prevailing links between exports and economic growth in Slovenian case: first, vigorous output growth provides the necessary sustainability of currently executed or planned structural reforms, and second, strong growth of the Slovenian economy also fosters the process of catching-up with EU-countries. 
The paper's goal is to identify the possible relationship(s) between exports and economic growth in the transition phase of the Slovenian economy. At the outset of the paper the pace of the transition process of the Slovenian economy to the market oriented regime is given in light of key macroeconomic aggregates. The relevant testing methodology and the empirical results are presented in the second and third part of the article. The last section refers to conclusions.

\section{Macroeconomic Trends in the Slovenian Economy}

Slovenia became an independent state in June 1991 with the break-up of Yugoslavia. The disintegration of the common Yugoslav market triggered two parallel processes in Slovenia: the need to re-orient domestic production and trade towards international markets, and to cope with the following break out of transformation depression. The latter was caused by substantial losses of export markets as well as by an inappropriate domestic production structure inherited from the Yugoslav economic system.

The beginning of economic transformation reflected itself predominantly through shocks in foreign trade. Thus, from 1990 to 1993, the cumulative exports and imports of goods and services of Slovenian enterprises was cut down in real terms by 48.3 per cent and by 32.5 per cent, respectively. In this period the largest drops were recorded particularly in exports and imports from the regions of former Yugoslavia: exports dropped by 87.9 per cent and imports by 85.9 per cent in real terms. In 1990, former Yugoslavia accounted for 61.8 per cent of Slovenia's commodity and service sales, whereas in 1993 this portion fell to 16.4 per cent. Therefore, within three ye-

Table 1

Selected Macroeconomic Indicators of the Slovenian Economy

\begin{tabular}{|l|c|c|c|c|c|c|c|}
\hline Economic indicator/Year & 1992 & 1993 & 1994 & 1995 & 1996 & 1997 & 1998 \\
\hline GDP per capita (in USD) & 6275 & 6366 & 7233 & 9431 & 9481 & 9163 & 9878 \\
\hline $\begin{array}{l}\text { Exports of goods and } \\
\text { services per capita (in } \\
\text { constant USD; 1995 = 100) }\end{array}$ & 4779 & 4711 & 5052 & 5138 & 5137 & 5678 & 6064 \\
\hline $\begin{array}{l}\text { Exports of goods per } \\
\text { capita (in constant USD; } \\
1995=100 \text { ) }\end{array}$ & 4172 & 3977 & 4137 & 4205 & 4162 & 4657 & 5054 \\
\hline Rate of inflation (CPI) & 207.3 & 32.9 & 21.0 & 13.5 & 9.9 & 8.4 & 8.0 \\
\hline $\begin{array}{l}\text { Standardised rate of } \\
\text { unemployment (ILO) }\end{array}$ & 8.3 & 9.1 & 9.0 & 7.4 & 7.3 & 7.4 & 7.9 \\
\hline $\begin{array}{l}\text { Domestic exports to EU } \\
\text { (in \% of total exports) }\end{array}$ & 60.8 & 63.2 & 65.6 & 67.0 & 64.6 & 63.6 & 65.5 \\
\hline $\begin{array}{l}\text { Domestic imports from EU } \\
\text { (in \% of total imports) }\end{array}$ & 60.0 & 65.6 & 69.2 & 68.9 & 67.6 & 67.4 & 69.4 \\
\hline Terms of trade & 103 & 111 & 105 & 103 & 102 & 100 & 103 \\
\hline $\begin{array}{l}\text { Current account balance } \\
\text { (in USD million) }\end{array}$ & 926 & 192 & 573 & -99 & 31 & 11 & -147 \\
\hline
\end{tabular}

1) The indices are calculated from USD values, exports and imports without processing; Fisher type indices; average of previous year $=100$.

Source: Statistical Yearbook of the Republic of Slovenia, various issues; author's calculations. 
ars, the amount of goods and services exported to non-Yugoslav markets increased by 45.4 percentage points. Between 1992 and 1993, the re-orientation of Slovenian foreign trade flows towards international, predominantly European markets, mainly ended. From 1986 to the end of 1995, the proportion of exports to the EU of total Slovenian exports of goods increased from 20 per cent to 67 per cent. Similar figures can also be found for import flows. While in 1986, the EU accounted only for 25 per cent of Slovenian imports, in 1995 its share reached 69 per cent (see Table $1)$.

Development in foreign trade could not leave the growth dynamics of GDP untouched. In the period 1991-1992, the Slovenian GDP fell cumulatively by 14.4 per cent. However, the exit from transformation depression started already in 1993, when GDP growth attained 2.8 per cent over the year (see Table 2). Domestic demand contributed the most to the recovery of GDP growth. The output growth in 1993 was induced with the increase of private consumption, generated predominantly by rising nominal wages and decelerating inflation. In subsequent years, economic growth gained momentum, so that in 1996 the GDP reached its pre-independence level. The resurgence of domestic growth was accompanied by successful lowering of inflation and stabilization of the unemployment rate (see Table 1). After 1993, the economic recovery as well as the continuation of market-oriented economic reforms were importantly facilitated by a favorable international environment. Robust foreign demand on Slovenia's main export markets ${ }^{1)}$ and increasing terms of trade (see Table 1) enabled domestic policy makers to continue with macroeconomic stabilization without endangering the regained economic growth.

Table 2

Expenditure on Slovenian Gross Domestic Product

\begin{tabular}{|l|r|r|r|r|r|r|c|}
\hline $\begin{array}{l}\text { Real growth in \%, } \\
\text { constant SIT prices 1995 }\end{array}$ & 1992 & 1993 & 1994 & 1995 & 1996 & 1997 & 1998 \\
\hline Final consumption & -3.1 & 11.6 & 3.4 & 7.5 & 2.7 & 3.6 & 3.0 \\
\hline Private consumption & -3.6 & 13.9 & 3.8 & 9.2 & 2.4 & 3.3 & 2.4 \\
\hline Government consumption & -1.7 & 5.3 & 2.1 & 2.5 & 3.6 & 4.3 & 4.8 \\
\hline Gross capital formation & -3.7 & 20.5 & 14.2 & 23.3 & 4.2 & 10.1 & 13.7 \\
\hline Exports of goods and services & -23.5 & 0.6 & 10.5 & 1.0 & 3.3 & 11.3 & 6.8 \\
\hline Imports of goods and services & -22.9 & 17.6 & 10.7 & 11.6 & 2.4 & 12.2 & 9.7 \\
\hline Gross domestic product & -5.5 & 2.8 & 5.3 & 4.1 & 3.5 & 4.6 & 3.9 \\
\hline
\end{tabular}

Source: Bank of Slovenia, Monthly Bulletin, various issues; Slovenian Economic Mirror, various issues.

In the period of temporary weakening of exports, in 1995, causing a worsening in the country's current account position, private consumption coupled with strong imports played the biggest part in the maintenance of output growth. After 1996, GDP growth was predominantly stimulated through foreign demand - with the ex-

1) The correlation coefficient between the growth of real exports and the growth of foreign imports for 1992-1998, measured as a weighted average of import demand of eight Slovenian trading partners (Germany, France, Italy, Austria, the Netherlands, Switzerland, the United Kingdom and the United States), reached 0.872 . In 1998, the selected countries absorbed 64.4 per cent of Slovenian exports and covered 67.0 per cent of total imports. 
ception of 1993 and 1995, output growth virtually coincided with the expansion of domestic exports of goods and services.

Strong orientation of production towards international markets in the period of transition, as one of the factors markedly shaping the structure of the domestic export supply, resulted in a growing dependence of the Slovenian economy on its foreign trade performance (see Bekő, 1999). A high degree of openness - in 1998 the foreign trade-output ratio amounted to 1.15 - illustrates the extent to which output growth is influenced by foreign demand, i.e. by Slovenia's ability to expand foreign trade. The macroeconomic picture presented leads us to the need for thoroughly analysis of the empirical nature of export-GDP link. Due to the data problems prior to 1992 and to avoid possible "breaks" in the relevant time series because of the introduction of VAT in July 1999, this notion will be scrutinized in the upcoming sections by concentrating mainly on the period briefly described in the present section.

\section{Causality Examination of the Export-Output Re- I a tions i p}

The causal relationship between exports and economic growth has been tested in two steps. The first step required establishing the order of integration for each variable. This has been done with the standard Augmented Dickey-Fuller (ADF) test. Since the true order of augmentation of the Dickey-Fuller test is unknown ex ante, a two-step procedure was necessary. In the first step, various model selection criteria were used to detect the order of the ADF regression, and in the next step, the actual test of the unit root was performed. In the present analysis, the selection of the order of augmentation in ADF regression was based upon Akaike information criterion (AIC) and Schwarz Bayesian criterion (SBC). The ADF regressions of loglevel data included an intercept and a linear trend, whereas for data in difference form, no trend was included. Besides the evaluation of the non-seasonal properties of data, testings for seasonal integration were made. For this purpose the DHF test, introduced by Dickey, Hasza and Fuller (1984) and modified by Osborn et al. (1988), was applied relying on the same order specification of equations as in ADF test.

The ADF and DHF tests were executed on GDP variable as well as on all export variables currently and officially available for Slovenian economy. All primary data employed have been obtained from the databases of the Bank of Slovenia. The ADF and DHF integration tests for the logarithms of relevant time series in levels, first differences and, when needed, second differences on quarterly data are detailed in Table 3.

In the time series stationarity is mainly reached only after the variables are expressed in first difference form. Tests for seasonal integration reject the null hypothesis of the existence of a seasonally integrated process for GDP as well as for all export variables. To find cointegration between selected variables, the cointegrating relationships have to include only I(1) variables or, in case of seasonal data, the same order of seasonally integration among the variables is required. As the AIC values for ADF and DHF tests in Table 3 testify this assumption is fulfilled for the observed variables.

Once it has been established which of the available variables had compatible orders of integration, the second step determined whether there was at least one linear combination of them that was stationary. If such a linear combination exists, the variables are said to be cointegrated and the specific values of the stationary linear combinations are marked as cointegrating vectors. To establish the cointegrating properties of selected data we used the procedure established by Johansen 
Table 3

ADF and DHF Integration Tests for Selected Variables ${ }^{1)}$

\begin{tabular}{|c|c|c|c|c|c|c|c|c|}
\hline Variables/ tests & AIC(Order) & \begin{tabular}{|c|} 
Levels; \\
variable $v_{t}^{3)}$
\end{tabular} & SBC(Order) & \begin{tabular}{|c|} 
Levels; \\
variable $v_{t}^{3)}$
\end{tabular} & AIC(Order) & Differences & SBC(Order) & Differences \\
\hline $\begin{array}{l}\log G D P \\
\text { (ADF) }\end{array}$ & $65.8393(5)$ & -2.8133 & $56.1454(2)$ & $-5.8492^{*}$ & $58.8502(2)$ & $-10.7345^{\star}$ & $56.6681(2)$ & $-10.7345^{*}$ \\
\hline $\begin{array}{l}\log \text { GDP } \\
(\mathrm{DHF})^{4)}\end{array}$ & $53.8246(5)$ & $(-2.1406)^{*}$ & $50.7083(5)$ & $(-2.1406)^{*}$ & & & - & - \\
\hline $\begin{array}{l}\log \text { EX\$ } \\
\text { (ADF) }\end{array}$ & $34.2371(4)$ & -2.7470 & $31.0618(2)$ & -1.9717 & $29.9974(2)$ & $-3.3956^{*}$ & \begin{tabular}{|l|}
$29.1540(1)$ \\
$24.8595(1)$
\end{tabular} & $\begin{array}{l}-2.4216 \\
-4.3283^{* 21}\end{array}$ \\
\hline $\begin{array}{l}\log \text { EX\$ } \\
\left.(\mathrm{DHF})^{4}\right)\end{array}$ & $22.7155(5)$ & $(-2.1795)^{*}$ & $19.1540(5)$ & $(-2.1795)^{*}$ & - & - & - & - \\
\hline $\begin{array}{l}\text { log EXCON\$ } \\
\text { (ADF) }\end{array}$ & $38.9347(4)$ & -2.8246 & $35.8711(2)$ & -2.6882 & $34.5553(2)$ & $-3.2114^{*}$ & $32.3732(2)$ & $-3.2114^{*}$ \\
\hline $\begin{array}{l}\log \text { EXCON\$ } \\
(\mathrm{DHF})^{4)}\end{array}$ & $28.8122(4)$ & $(-2.8224)^{*}$ & $26.5863(4)$ & $(-2.8224)^{\star}$ & - & - & - & - \\
\hline $\begin{array}{l}\log E X Q \\
\text { (ADF) }\end{array}$ & $35.2573(2)$ & -3.4127 & $32.8978(1)$ & -3.1430 & $32.1253(4)$ & $-4.3855^{*}$ & $29.5155(2)$ & $-5.0870^{*}$ \\
\hline $\begin{array}{l}\log \text { EXQ } \\
(\mathrm{DHF})^{4)}\end{array}$ & $25.7329(4)$ & $(-3.5008)^{*}$ & $23.5069(4)$ & $(-3.5008)^{*}$ & - & - & - & - \\
\hline $\begin{array}{l}\log \text { EXCOMSER } \\
\text { (ADF) }\end{array}$ & $31.2170(4)$ & -2.1745 & $27.0292(1)$ & -1.1849 & $26.7975(1)$ & $-3.6313^{*}$ & \begin{tabular}{|l|}
$24.6944(3)$ \\
$23.1591(2)$ \\
\end{tabular} & $\begin{array}{l}-1.8681 \\
-5.3623^{* 2)} \\
\end{array}$ \\
\hline $\begin{array}{l}\log \text { EXCOMSER } \\
(\mathrm{DHF})^{4)}\end{array}$ & $25.6872(4)$ & $(-2.6044)^{*}$ & $23.4613(4)$ & $(-2.6044)^{*}$ & & $\cdot$ & - & - \\
\hline
\end{tabular}

1) $A\left({ }^{*}\right)$ indicates significance at the $5 \%$ level.

2) Second difference.

3) The DHF test was applied in the form: $\Delta_{s} \log y_{t}=\alpha \log v_{t-s}+\sum_{i=1}^{p} \alpha_{i} \Delta_{s} \log y_{t-i}+\varepsilon_{t} ; t-$ statistic for the variable $v_{t}$ in parentheses.

4) DHF lower critical value at the $5 \%$ level of significance (no constant): -1.94 ; DHF upper critical value at the $5 \%$ level of significance (no constant): -1.87 .

Source: Charemza and Deadman, 1997.

List of used variables and their specification (1992:Q1 - 1999:Q1):

GDP - $\quad$ gross domestic product in constant SIT prices 1995;

EXCOMSER - exports of goods and services in USD and in constant exchange rates $(1995=100)$; FOB-type valuation for exported goods;

EXCON\$ - $\quad$ exports of goods in USD and in constant exchange rates $(1995=100)$; FOB-type va-

EX\$ - $\quad$ luation; $\quad$ exports of goods in USD; FOB-type valuation;

EXQ - $\quad$ exports of goods in USD, deflated with respect to inter-currency changes $(1995=100)$ and adjusted for the influence of prices in foreign markets; FOB-type valuation.

(1991). The results of the Johansen's cointegration tests in Table 4 show that the null hypothesis of non-cointegration can be rejected at least at the 5 per cent level for selected export variables.

Since the cointegration analysis makes no assumptions about the direction of causality, the results in Table 4 cannot be interpreted as direct evidence of the causal relationship between exports and output. On the other hand, the standard, Granger causality test is only valid if the original time series are not cointegrated. In the case of cointegration, results of causality tests may be biased, since the standard causality tests frequently fail to detect a causal relation, even if it is in fact present (see Granger, 1988). Based upon the results in Table 4, export variables and GDP 
Table 4

The Results of Johansen's Cointegration Test ${ }^{1)}$

\begin{tabular}{|l|l|l|c|r|r|}
\hline \multicolumn{5}{|c|}{ Cointegration LRS test } \\
\hline Variable & $\mathrm{H}_{0}$ & $\mathrm{H}_{1}$ & LRS & $5 \% \mathrm{CV}$ & $1 \% \mathrm{CV}$ \\
\hline $\log ($ EXCOMSER) & $\mathrm{r}=0$ & $\mathrm{r}=1$ & 30.678 & 19.96 & 24.60 \\
& $\mathrm{r} \leq 1$ & $\mathrm{r}=2$ & 9.005 & 9.24 & 12.97 \\
\hline Variable & $\mathrm{H}_{0}$ & $\mathrm{H}_{1}$ & LRS & $5 \% \mathrm{CV}$ & $1 \% \mathrm{CV}$ \\
\hline $\log ($ EXCON\$) & $\mathrm{r}=0$ & $\mathrm{r}=1$ & 33.609 & 19.96 & 24.60 \\
& $\mathrm{r} \leq 1$ & $\mathrm{r}=2$ & 3.876 & 9.24 & 12.97 \\
\hline Variable & $\mathrm{H}_{0}$ & $\mathrm{H}_{1}$ & LRS & $5 \% \mathrm{CV}$ & $1 \% \mathrm{CV}$ \\
\hline $\log (\mathrm{EX} \$)$ & $\mathrm{r}=0$ & $\mathrm{r}=1$ & 21.569 & 19.96 & 24.60 \\
& $\mathrm{r} \leq 1$ & $\mathrm{r}=2$ & 5.340 & 9.24 & 12.97 \\
\hline Variable & $\mathrm{H}_{0}$ & $\mathrm{H}_{1}$ & LRS & $5 \% \mathrm{CV}$ & $1 \% \mathrm{CV}$ \\
\hline $\log (\mathrm{EXQ})$ & $\mathrm{r}=0$ & $\mathrm{r}=1$ & 34.318 & 19.96 & 24.60 \\
& $\mathrm{r} \leq 1$ & $\mathrm{r}=2$ & 7.722 & 9.24 & 12.97 \\
\hline
\end{tabular}

1) All the variables were normalized with respect to log (GDP). LRS stands for the likelihood ratio statistics, $5 \%$ CV for the 5 per cent critical value and $1 \%$ CV for the 1 per cent critical value.

share cointegrating properties. According to the Granger Representation Theorem (see Engle, Granger, 1991), if two time series are cointegrated then an error-correction mechanism exists and vice versa. Empirically, significant error-correction term provides additional evidence on the presence of long-term relationship between the analysed variables. With respect to detection of causality, Granger (1988) stressed that if two variables are found to be cointegrated, then causality must exist in at least one direction, since in case of cointegration at least one variable helps to predict the movement of the other. This requires the testing of the relationship between export-output variables for Granger causality with error-correction model. Assessment of causality within error-correction model is additionally justified with the following argument. Differencing the analyzed data causes the loss of all information about their long run characteristics, so that the Granger causality tests limit themselves only to the search of the short term relationships between variables. The examination of the long term properties of data by addressing their causality is therefore possible only when the relevant error-correction term, obtained from the cointegrating regression, is included in the standard causality test. The augmented Granger causality test is in such case formulated as:

$$
\begin{aligned}
& D Y_{t}=a_{0}+\sum_{i=1}^{j} a_{i} D Y_{t-i}+\sum_{i=1}^{k} b_{i} D X_{t-i}-\lambda \mu_{t-1}+\varepsilon_{1 t} \\
& D X_{t}=c_{0}+\sum_{i=1}^{l} c_{i} D X_{t-i}+\sum_{i=1}^{m} d_{i} D Y_{t-i}-\delta v_{t-1}+\varepsilon_{2 t}
\end{aligned}
$$

where $\varepsilon_{1 t}$ and $\varepsilon_{2 t}$ are zero mean, serially uncorrelated random terms, while $\mu_{t-1}$ and $v_{t-1}$ are the lagged error-correction terms derived from the cointegrating regressions of the form:

$$
\begin{aligned}
& \mu_{t}=Y_{t}-a-b X_{t} \\
& v_{t}=X_{t}-c-d Y_{t}
\end{aligned}
$$


Letter $D$ represents first differences in (1) and (2). The interpretation of causality in both equations specified above is similar as in the standard Granger causality model. Within the augmented Granger causality model, however, two possible sources of causality can be identified. Changes in $X_{t}$ or $Y_{t}$ or in both are partly driven by $\mu_{t-1}$ or $v_{t-1}$, which themselves are a linear combination of $X_{t-1}$ and $Y_{t-1}$, and also by lagged values of both variables. For example, $Y_{t}$ can be caused by $X_{t-1}$ either through $\mu_{t-1}$, which is itself a function of lagged $X_{t}$ and $Y_{t}$ if $\lambda \neq 0$, or through lagged $X_{t}$. Considering equation (1), $X_{t}$ is said to Granger cause $Y_{t}$ not only if $b_{i}$ is significant but also if $\lambda$ is significant. Thus, unlike the standard Granger causality test, the errorcorrection model allows for the finding that exports cause output as long as the error-correction term, $\lambda$, is significant even if $b_{i}$ appears to be insignificant. Changes in the lagged variable describe the short causal impact, while the error-correction term captures the long term effect (see Jones, Joulfaian, 1991). Since the detection (direction) of causality strongly depends on the number of included lagged terms (see Thornton, Batten, 1985) a diagnostic method was carried out to identify the proper lag length. For the determination of the optimal lags the Akaike's (1970) final prediction error (FPE) criterion was used, following the procedure suggested by Hsiao $(1979,1981)$. Evidence about the long-term causality from error-correction analysis is presented in Table $5-8$.

Table 5

Augmented Granger Causality Test for DEXCOMSER and DGDP')

\begin{tabular}{|l|c|c|}
\hline $\mathrm{H}_{0}$ & DEXCOMSER does not cause DGDP & DGDP does not cause DEXCOMSER \\
\hline Optimal Lags & $j=6 ; k=1$ & $I=7 ; m=1$ \\
\hline F-statistics & $(1,13) ; 1.396$ & $(1,12) ; 8.256^{* *}$ \\
\hline ECT $(-1)$ & $-0.763^{*}(-1.958)$ & $-0.057^{* *}(-2.224)$ \\
\hline
\end{tabular}

1) Numbers in parentheses by $F$-statistics are degrees of freedom and by error-correction term ECT(-1) the $t$-statistics. A $\left({ }^{*}\right)$, or $\left({ }^{* *}\right)$ indicate significance at the $10 \%$ or $5 \%$ level, respectively.

Table 6

Augmented Granger Causality Test for DEXCON\$ and DGDP1)

\begin{tabular}{|l|c|c|}
\hline $\mathrm{H}_{0}$ & DEXCON\$ does not cause DGDP & DGDP does not cause DEXCON\$ \\
\hline Optimal Lags & $j=6 ; k=4$ & $I=7 ; m=3$ \\
\hline F-statistics & $(4,10) ; 2.805^{*}$ & $(3,10) ; 3.548^{*}$ \\
\hline ECT $(-1)$ & $-0.800^{* *}(-2.270)$ & $-0.265^{\star * *}(-3.292)$ \\
\hline
\end{tabular}

1) Numbers in parentheses by $F$-statistics are degrees of freedom and by error-correction term ECT(-1) the $t$-statistics. $A\left({ }^{*}\right),\left({ }^{* \star}\right)$ or $\left({ }^{* * \star}\right)$ indicate significance at the $10 \%, 5 \%$ or $1 \%$ level, respectively. 
Table 7

Augmented Granger Causality Test for DEX\$ and DGDP1)

\begin{tabular}{|l|c|c|}
\hline $\mathrm{H}_{0}$ & DEX\$ does not cause DGDP & DGDP does not cause DEX\$ \\
\hline Optimal Lags & $j=6 ; k=5$ & $I=1 ; m=6$ \\
\hline F-statistics & $(5,9) ; 2.546$ & $(6,13) ; 2.338^{\star}$ \\
\hline ECT $(-1)$ & $-0.302(-0.749)$ & $-0.189^{\star *}(-2.375)$ \\
\hline
\end{tabular}

1) Numbers in parentheses by $F$-statistics are degrees of freedom and by error-correction term ECT(-1) the $t$-statistics. A $\left({ }^{*}\right)$ or $\left({ }^{* *}\right)$ indicate significance at the $10 \%$ or $5 \%$ level, respectively.

Table 8

Augmented Granger Causality Test for DEXQ and DGDP'1)

\begin{tabular}{|l|c|c|}
\hline $\mathrm{H}_{0}$ & DEXQ does not cause DGDP & DGDP does not cause DEXQ \\
\hline Optimal Lags & $j=4 ; k=4$ & $I=3 ; m=3$ \\
\hline F-statistics & $(4,14) ; 3.812^{* *}$ & $(3,16) ; 1.955$ \\
\hline ECT $(-1)$ & $-0.218^{*}(-1.964)$ & $-0.917^{* *}(-2.281)$ \\
\hline
\end{tabular}

1) Numbers in parentheses by $F$-statistics are degrees of freedom and by error-correction term ECT(-1) the $t$-statistics. A $\left({ }^{*}\right)$ or $\left({ }^{* \star}\right)$ indicate significance at the $10 \%$ or $5 \%$ level, respectively.

Results from the augmented Granger causality test indicate bi-directional causality between chosen export variables and real GDP. The only relation where a significant cointegration is reported, however, only one-way causality was found, running from real output towards exports, is the one between DEX $\$$ and DGDP (see Table 7). In addition, existence of long term bi-directional causality (ECT) supplements the evidence on the short term causality in two cases: between DEXCOMSER and DGDP, and between DEXQ and DGDP.

\section{Extension to Disaggregated Analysis}

While the previous section operated with aggregate data, the attention in the present section is turned to the evaluation of the export-output link at the sectoral level. This approach seems to be important (see e.g. Giles et al., 1993), the more so, because the use of aggregated data implies that the estimates of causal channels are also valid for all sectors of the economy. To the extent that this is not the case, the trade flow and output specification masks potentially useful information with regard to sectoral peculiarities. Causality tests at the aggregate level may also include the possibility of spurious association between exports and output common in the aggregate data (see Giles, Williams, 2000a, 2000b). Therefore a sectoral decomposition of export flows and production within the manufacturing was applied to detect additional causality patterns. For this purpose we utilized the Granger-Sims causality framework (see Sims, 1972) holding very closely to the method introduced by Sargent and Wallace (1973). The Granger-Sims causality model, after incorporating conditionality, is defined with the following pairs of linear equations:

$$
Y_{t}=\alpha+\beta \delta+\sum_{i=0}^{k} b_{i} X_{t-i}+\varepsilon_{t}
$$




$$
Y_{t}=\alpha+\beta \delta+\sum_{i=0}^{k} b_{i} X_{t-i}+\sum_{j=1}^{l} c_{j} X_{t+j}+v_{t}
$$

and

$$
\begin{gathered}
X_{t}=\alpha^{\prime}+\beta^{\prime} \delta+\sum_{i=0}^{m} b_{i} Y_{t-i}+\varepsilon_{t}^{\prime} \\
X_{t}=\alpha^{\prime}+\beta^{\prime} \delta+\sum_{i=0}^{m} b_{i} Y_{t-i}+\sum_{j=1}^{n} c_{j}^{\prime} Y_{t+j}+v_{t}^{\prime}
\end{gathered}
$$

where $\varepsilon_{t}, \varepsilon_{t}{ }^{\prime}, v_{t}, v_{t}{ }^{\prime}$ are zero mean, serially uncorrelated random terms, while $\delta$ represents a set of variables, which are defined as exogenous, and appear as conditional factors in the causal relation.

The operation of causality within the conditional Granger-Sims model can be interpreted as follows:

$-X$ causes $Y$ if $\mathrm{H}_{0}: c_{j}=0$, for $j=1,2, \ldots, I$, cannot be rejected and $\mathrm{H}_{0}: c_{j}{ }^{\prime}=0$, for $j=1,2, \ldots, n$, can be rejected;

$-Y$ causes $X$ if $\mathrm{H}_{0}: c_{j}^{\prime}=0$, for $j=1,2, \ldots, n$, cannot be rejected and $\mathrm{H}_{0}: c_{j}=0$, for $j=1,2, \ldots, l$, can be rejected;

- bi-directional causality exists if both $\mathrm{H}_{0}: c_{j}=0$, for $j=1,2, \ldots, I$, and $\mathrm{H}_{0}: c_{j}{ }^{\prime}=0$, for $j=1,2, \ldots, n$, can be rejected.

The main advantage of the specifications (5)-(8) is that they allow us to focus on the examined causal relationship, while at the same time enabling the control of selected variables, which otherwise might affect the investigated sectoral causality. The conditional Granger-Sims test also helps to avoid the "omitted variable" as well as "spurious causality" problem and, according to the so far executed tests on Slovenian data (see Bole, 1994), should be particularly pertinent for short time series analysis.

Because the feedback impact of causality model is tested in the reduced form, it is necessary to specify the conditional variables included in the model in advance. Besides the variable representing foreign demand (labeled as FORDEMAND), we used the corresponding import variables as the second conditional factor, basically due to their solid performance in the balance-of-payments constrained growth model (see Bekő, 2000b). The causality between sectoral exports and sectoral production was tested by fixing the influence of sectoral imports and the effect of foreign demand.

The sectoral variables comprised 15 manufacturing sectors listed by NACE classification Rev. 1 (Nomenclature statistique des activites economique dans la Communauté européenne). To obtain precise information about which sector is the enduser of imported goods and which sector is the final exporter of registered product group, exports and imports were sorted into individual sections of NACE with regard to the branch into which a particular product belongs. The sectoral data coverage employed in causality examination is solid, since in the period $1992-1998$ exports of goods classified within manufacturing represented on average 87 per cent of total Slovenian commodity exports. ${ }^{2)}$ To keep the output variables consistent with the sectoral classification of trade flows, the production volumes of particular manufacturing industries were selected as the output measures for causality tests. All data were compiled from the databases of the Bank of Slovenia.

2) The corresponding manufacturing imports covered in the same period on average 55 per cent of Slovenia's total commodity imports. 
For the accurate treatment of the lag structure with the FPE criterion, the causality specification allowed the extension of the model till six lags. ${ }^{3)}$ The calculated $F$ statistics are used to test the hypothesis that coefficients for future values of the independent variable are jointly equal to zero. The Breusch-Godfrey LM test served as a detector of possible first order-serial correlation. In cases, where autocorrelation emerged, the Cochrane-Orcutt two-stage procedure was employed in order to tackle the problem. Operation with stationary data required preliminary testing for the presence of unit roots. The results of sectoral ADF tests, following the same estimation procedure as by aggregate data analysis, are summarized in Tables $9-11$.

Table 9

ADF Tests for Exports in Manufacturing')

\begin{tabular}{|c|c|c|c|c|c|c|c|c|}
\hline Variables & AIC(Order) & Levels & SBC(Order) & Levels & AIC(Order) & Differences & SBC(Order) & Differences \\
\hline $\log$ EXD & $38.1442(4)$ & -2.7597 & $34.1700(4)$ & -2.7597 & $33.1843(2)$ & $-3.0040^{*}$ & $\begin{array}{l}31.0648(1) \\
27.7322(2)\end{array}$ & $\begin{array}{l}-2.4360 \\
-4.7665^{* 21}\end{array}$ \\
\hline $\log$ EXDA & $16.5799(4)$ & -2.0898 & $13.0662(2)$ & -3.5632 & $14.8339(2)$ & $-5.9504^{*}$ & $12.6518(2)$ & $-5.9504^{\star}$ \\
\hline $\log$ EXDB & $39.5458(2)$ & -2.5292 & $36.7071(2)$ & -2.5292 & $36.6043(1)$ & $-3.3830^{*}$ & $34.9678(1)$ & $-3.3830^{*}$ \\
\hline $\log$ EXDC & $21.0493(4)$ & -2.9055 & $19.2050(1)$ & -2.3883 & 17.9494(1) & $-3.7618^{*}$ & $16.3128(1)$ & $-3.7618^{*}$ \\
\hline $\log$ EXDD & $23.0526(4)$ & -2.3589 & $19.0784(4)$ & -2.3589 & \begin{tabular}{|l|}
$19.0624(4)$ \\
$17.4738(2)$ \\
\end{tabular} & $\begin{array}{l}-1.7391 \\
-8.4169^{* 22} \\
\end{array}$ & $\begin{array}{l}16.3296(3) \\
15.3847(2) \\
\end{array}$ & $\begin{array}{l}-1.3253 \\
-8.4169^{* 22} \\
\end{array}$ \\
\hline $\log$ EXDE & $27.7002(1)$ & -1.9081 & 25.4 & -1.9081 & $\begin{array}{l}23.8618(1) \\
19.8586(1)\end{array}$ & $\begin{array}{l}-2.8832 \\
-5.2441^{\star 22}\end{array}$ & $\begin{array}{l}22.2252(1) \\
18.2918(1)\end{array}$ & $\begin{array}{l}-2.8832 \\
-5.2441^{* 22}\end{array}$ \\
\hline $\log$ EXDF & $-12.1873(1)$ & -2.7182 & $-14.4583(1)$ & -2.7182 & $-14.6528(1)$ & $-3.6528^{*}$ & $-16.1695(1)$ & $-3.6528^{*}$ \\
\hline $\log$ EXDG & $28.7560(4)$ & -2.4385 & $24.7818(4)$ & -2.4385 & $22.2669(2)$ & $-4.0735^{*}$ & $\begin{array}{l}20.3752(3) \\
20.5352(2) \\
\end{array}$ & $\begin{array}{l}-1.7261 \\
-7.2455^{\star 2}\end{array}$ \\
\hline $\log$ EXDH & $29.4287(1)$ & -1.0305 & $27.1577(1)$ & -1.0305 & $29.0051(2)$ & $-3.3144^{*}$ & $26.8230(2)$ & $-3.3144^{*}$ \\
\hline $\log$ EXDI & $36.4298(4)$ & $-3.6278^{*}$ & $32.4551(4)$ & $-3.6278^{*}$ & $33.3865(2)$ & $-4.6270^{*}$ & $31.2045(2)$ & $-4.6270^{*}$ \\
\hline $\log$ EXDJ & $32.6518(1)$ & -1.8724 & $30.3808(1)$ & -1.8724 & $29.3824(1)$ & $-3.2300^{*}$ & $27.7458(1)$ & $-3.2300^{*}$ \\
\hline $\log$ EXDK & 28.2431(2) & -2.5839 & $25.4044(2)$ & -2.5839 & $24.7374(2)$ & $-3.6999^{*}$ & $23.0237(1)$ & $-3.5066^{*}$ \\
\hline $\log$ EXDL & $22.9775(2)$ & -1.7389 & $21.4212(1)$ & -1.6992 & $\begin{array}{l}29.4730(3) \\
32.3438(2)\end{array}$ & $\begin{array}{c}-1.2819 \\
-13.5790^{* 21}\end{array}$ & $\begin{array}{l}26.7454(3) \\
30.2547(2)\end{array}$ & $\begin{array}{c}-1.2819 \\
-13.5790^{\star 2}\end{array}$ \\
\hline $\log$ EXDM & $13.8951(4)$ & -2.5661 & $9.9209(4)$ & -2.5661 & $11.8485(2)$ & $-6.5245^{*}$ & $9.6664(2)$ & $-6.5245^{\star}$ \\
\hline $\log$ EXDN & $30.2490(4)$ & -1.8948 & $26.2748(4)$ & -1.8948 & $28.9295(2)$ & $-5.9093^{*}$ & $26.7474(2)$ & $-5.9093^{\star}$ \\
\hline
\end{tabular}

1) A $\left(^{*}\right)$ indicates significance at the 0.05 level.

2) Second difference.

List of used variables and their specification (1992:Q1 - 1999:Q1):

EXD - exports of goods in USD (manufacturing-total), constant exchange rates $(1995=100)$; FOB-type valuation;

EXDA - exports of goods in USD (manufacture of food products, beverages and tobacco), constant exchange rates $(1995=100)$; FOB-type valuation;

EXDB - exports of goods in USD (manufacture of textiles and textile products), constant exchange rates $(1995=100)$; FOB-type valuation;

EXDC - exports of goods in USD (manufacture of leather and leather products), constant exchange rates $(1995=100)$; FOB-type valuation;

3) The calculations of optimal lag structures with FPE for all variables used in this article are available from the author upon request. 
EXDD - exports of goods in USD (manufacture of wood and wood products, except furniture), constant exchange rates $(1995=100)$; FOB-type valuation;

EXDE - exports of goods in USD (manufacture of pulp, paper and paper products; publishing and printing), constant exchange rates $(1995=100)$; FOB-type valuation;

EXDF - exports of goods in USD (manufacture of coke, refined petroleum products and nuclear fuel), constant exchange rates $(1995=100)$; FOB-type valuation;

EXDG - exports of goods in USD (manufacture of chemicals, chemical products and man-made fibres), constant exchange rates $(1995=100)$; FOB-type valuation;

EXDH - exports of goods in USD (manufacture of rubber and plastic products), constant exchange rates $(1995=100)$; FOB-type valuation;

EXDI - exports of goods in USD (manufacture of other non-metallic mineral products), constant exchange rates $(1995=100)$; FOB-type valuation;

EXDJ - exports of goods in USD (manufacture of basic metals and fabricated metal products), constant exchange rates $(1995=100)$; FOB-type valuation;

EXDK - exports of goods in USD (manufacture of machinery and equipment), constant exchange rates $(1995=100)$; FOB-type valuation;

EXDL - exports of goods in USD (manufacture of electrical and optical equipment), constant exchange rates $(1995=100)$; FOB-type valuation;

EXDM - exports of goods in USD (manufacture of transport equipment), constant exchange rates $(1995=100)$; FOB-type valuation;

EXDN - exports of goods in USD (manufacture of furniture n.e.c.), constant exchange rates $(1995=100)$; FOB-type valuation.

Table 10

ADF Tests for Industrial Production in Manufacturing ${ }^{1)}$

\begin{tabular}{|l|c|c|c|c|c|c|c|c|}
\hline Variables & AIC(Order) & $\begin{array}{l}\text { Absolute } \\
\text { Values }\end{array}$ & SBC(Order) & $\begin{array}{l}\text { Absolute } \\
\text { Values }\end{array}$ & AIC(Order) & Differences & SBC(Order) & Differences \\
\hline $\log$ INDD & $43.0087(2)$ & -2.6918 & $40.7186(1)$ & -2.3268 & $38.8116(2)$ & $-4.1036^{*}$ & $36.6295(2)$ & $-4.1036^{*}$ \\
\hline $\log$ INDDA & $31.9530(2)$ & $-10.3634^{*}$ & $29.1142(2)$ & $-10.3634^{*}$ & $27.0247(2)$ & $-13.6126^{*}$ & $24.8426(2)$ & $-13.6126^{*}$ \\
\hline $\log$ INDDB & $35.9122(5)$ & -2.7588 & $34.2642(1)$ & $-4.9236^{*}$ & $32.8784(2)$ & $-6.6032^{*}$ & $30.6963(2)$ & $-6.6032^{*}$ \\
\hline $\log$ INDDC & $33.6689(3)$ & -3.3385 & $30.8284(2)$ & -3.2030 & $28.7331(4)$ & $-3.2289^{*}$ & $26.9193(1)$ & -2.1672 \\
& & & & & & & $23.6271(1)$ & $-4.0621^{* 2)}$ \\
\hline $\log$ INDDD & $17.8102(1)$ & -2.2051 & $15.5392(1)$ & -2.2051 & $15.1545(1)$ & $-4.0582^{*}$ & $13.5179(1)$ & $-4.0582^{*}$ \\
\hline $\log$ INDDE & $31.4784(4)$ & -2.0928 & $28.0559(3)$ & -1.7231 & $24.9115(3)$ & -1.9934 & $22.1839(3)$ & -1.9934 \\
& & & & & $25.2347(5)$ & $\left.-4.4694^{* 2}\right)$ & $21.5789(5)$ & $-4.4694^{* 2}$ \\
\hline $\log$ INDDF & $-18.9897(1)$ & -2.9485 & $-21.2607(1)$ & -2.9485 & $-20.5786(1)$ & $-4.4076^{*}$ & $-22.2152(1)$ & $-4.4076^{*}$ \\
\hline $\log$ INDDG & $31.2025(3)$ & -1.4659 & $28.0794(1)$ & -2.4136 & $28.5781(2)$ & $-4.9155^{*}$ & $26.3960(2)$ & $-4.9155^{*}$ \\
\hline $\log$ INDDH & $33.8733(5)$ & $-3.7691^{*}$ & $29.8495(4)$ & $-4.0162^{*}$ & $21.2978(1)$ & $-3.8049^{*}$ & $20.1052(2)$ & $-4.2047^{*}$ \\
\hline $\log$ INDDI & $27.5087(5)$ & -2.8412 & $23.3527(3)$ & -1.9972 & $24.4195(2)$ & $-14.7369^{*}$ & $22.2374(2)$ & $-14.7369^{*}$ \\
\hline $\log$ INDDJ & $33.5682(5)$ & -3.1879 & $30.4106(1)$ & -2.2783 & $29.0338(1)$ & $-4.3091^{*}$ & $27.3972(1)$ & $-4.3091^{*}$ \\
\hline $\log$ INDDK & $18.3663(1)$ & -2.1232 & $16.0953(1)$ & -2.1232 & $17.1609(1)$ & $-4.6399^{*}$ & $15.5243(1)$ & $-4.6399^{*}$ \\
\hline $\log$ INDDL & $20.4823(4)$ & -1.1600 & $16.9261(3)$ & -0.7166 & $18.8876(2)$ & $-5.4345^{*}$ & $15.7625(1)$ & $-4.9775^{*}$ \\
\hline $\log$ INDDM & $10.4731(4)$ & -0.8342 & $7.8332(1)$ & -1.8010 & $10.1432(3)$ & -1.9885 & $7.4156(3)$ & -1.9885 \\
& & & & & $8.6510(4)$ & $-4.5916^{* 2)}$ & $5.6821(2)$ & $-8.4389^{* 2)}$ \\
\hline $\log$ INDDN & $26.2121(1)$ & -2.3428 & $23.9411(1)$ & -2.3428 & $23.4663(1)$ & $-3.4764^{*}$ & $21.8297(1)$ & $-3.4764^{*}$ \\
\hline
\end{tabular}

1) $A\left({ }^{*}\right)$ indicates significance at the 0.05 level.

2) Second difference.

List of used variables and their specification (1992:Q1 - 1999:Q1):

INDD - industrial production (manufacturing-total), (1995 = 100);

INDDA - industrial production (manufacture of food products, beverages and tobacco), $(1995=100)$; 
INDDB - industrial production (manufacture of textiles and textile products), (1995 = 100);

INDDC - industrial production (manufacture of leather and leather products), $(1995=100)$;

INDDD - industrial production (manufacture of wood and wood products, except furniture), $(1995=100)$;

INDDE - industrial production (manufacture of pulp, paper and paper products; publishing and printing), $(1995=100)$;

INDDF - industrial production (manufacture of coke, refined petroleum products and nuclear fuel), $(1995=100)$;

INDDG - industrial production (manufacture of chemicals, chemical products and man-made fibres), $(1995=100)$;

INDDH - industrial production (manufacture of rubber and plastic products), $(1995=100)$;

INDDI - industrial production (manufacture of other non-metallic mineral products), $(1995=100)$;

INDDJ - industrial production (manufacture of basic metals and fabricated metal products), $(1995=100)$

INDDK - industrial production (manufacture of machinery and equipment), (1995 = 100);

INDDL - industrial production (manufacture of electrical and optical equipment), (1995 = 100);

INDDM - industrial production (manufacture of transport equipment), (1995 = 100);

INDDN - industrial production (manufacture of furniture n.e.c.), $(1995=100)$.

Table 11

ADF Tests for Foreign Demand Variable and for Imports in Manufacturing ${ }^{1)}$

\begin{tabular}{|c|c|c|c|c|c|c|c|c|}
\hline Variables & AIC(Order) & Levels & SBC(Order) & Levels & AIC(Order) & Differences & SBC(Order) & Differences \\
\hline $\begin{array}{l}\log \\
\text { FORDEMAND }\end{array}$ & $84.4086(1)$ & -2.1973 & $78.9022(2)$ & -1.4581 & $101.8059(4)$ & $-8.4517^{*}$ & $99.4827(2)$ & $-5.6143^{*}$ \\
\hline $\log I M D$ & $28.8336(1)$ & -1.4565 & $26.5626(1)$ & -1.4565 & $27.0023(1)$ & $-3.8427^{*}$ & $25.3658(1)$ & $-3.8427^{\star}$ \\
\hline $\log$ IMDA & $25.8157(4)$ & -1.7270 & $22.2885(1)$ & -2.2829 & $21.7332(2)$ & $-5.0166^{*}$ & $19.5511(2)$ & $-5.0166^{*}$ \\
\hline $\log$ IMDB & $38.5081(5)$ & -1.5570 & $34.0153(2)$ & -2.5221 & $36.1458(4)$ & $-4.2973^{*}$ & $32.8726(4)$ & $-4.2973^{*}$ \\
\hline $\log I M D C$ & $21.8514(3)$ & -1.1902 & $20.5441(1)$ & -1.4267 & $21.0831(1)$ & $-3.5273^{*}$ & $19.4465(1)$ & $-3.5273^{*}$ \\
\hline $\log$ IMDD & $28.6815(2)$ & -3.3180 & $26.3738(1)$ & -3.0535 & $23.4272(2)$ & $-3.4465^{*}$ & $21.7925(1)$ & $-3.2698^{*}$ \\
\hline $\log$ IMDE & $27.2739(2)$ & -2.4573 & $24.4352(2)$ & -2.4573 & $\begin{array}{l}24.5929(5) \\
21.7328(4)\end{array}$ & $\begin{array}{l}-1.7501 \\
-3.1372^{* 2)}\end{array}$ & $\begin{array}{l}21.3171(1) \\
18.5992(4)\end{array}$ & $\begin{array}{l}-1.8890 \\
-3.1372^{* 2)}\end{array}$ \\
\hline $\log$ IMDF & $9.6876(1)$ & -0.5997 & $7.4166(1)$ & -0.5997 & $6.9669(1)$ & $-3.4672^{*}$ & $5.3304(1)$ & $-3.4672^{*}$ \\
\hline $\log$ IMDG & $32.4543(4)$ & -2.7021 & $28.4800(4)$ & -2.7021 & $\begin{array}{l}27.3627(4) \\
25.3691(2)\end{array}$ & $\begin{array}{c}-1.6466 \\
-10.8282^{\star 2)}\end{array}$ & $\begin{array}{l}24.0896(4) \\
23.2801(2)\end{array}$ & $\begin{array}{c}-1.6466 \\
-10.8282^{* 2)}\end{array}$ \\
\hline $\log I M D H$ & $12.0227(2)$ & $-4.9467^{*}$ & $9.1839(2)$ & $-4.9467^{\star}$ & $3.8878(4)$ & $-4.0119^{*}$ & $1.4753(1)$ & $-4.9114^{*}$ \\
\hline $\log \mid \mathrm{MDI}$ & $23.2508(3)$ & -1.2255 & $19.8443(3)$ & -1.2255 & $\begin{array}{l}23.0219(3) \\
19.5812(2)\end{array}$ & $\begin{array}{c}-2.3148 \\
\left.-12.3148^{\star 2}\right)\end{array}$ & $\begin{array}{l}18.8638(4) \\
16.2931(3)\end{array}$ & $\begin{array}{l}-2.0829 \\
-4.2191^{* 2}\end{array}$ \\
\hline $\log$ IMDJ & $24.4124(4)$ & -2.6874 & $20.4381(4)$ & -2.6874 & $\begin{array}{l}19.6482(3) \\
17.9611(2)\end{array}$ & $\begin{array}{l}-1.4441 \\
-5.9414^{* 2)}\end{array}$ & $\begin{array}{l}17.9842(1) \\
15.8724(2)\end{array}$ & $\begin{array}{l}-2.8821 \\
-5.9414^{* 21}\end{array}$ \\
\hline $\log$ IMDK & $19.9228(2)$ & -2.3770 & $17.4558(1)$ & -1.9570 & $16.9301(1)$ & $-3.7912^{*}$ & $15.2936(1)$ & $-3.7912^{*}$ \\
\hline $\log$ IMDL & $26.6713(3)$ & -0.8908 & $23.2648(3)$ & -0.8908 & $25.2923(2)$ & $-8.0714^{*}$ & $23.1103(2)$ & $-8.0714^{*}$ \\
\hline $\log$ IMDM & $7.5574(3)$ & -1.8132 & $4.8595(1)$ & $-4.5953^{*}$ & $7.0793(2)$ & $-7.3225^{*}$ & $4.8972(2)$ & $-7.3225^{\star}$ \\
\hline $\log$ IMDN & $24.5060(4)$ & -1.6312 & $21.0763(3)$ & -1.7353 & $\begin{array}{l}21.8959(3) \\
18.3230(2)\end{array}$ & $\begin{array}{c}-2.4406 \\
-11.9690^{* 2}\end{array}$ & $\begin{array}{l}19.1683(3) \\
16.2339(2)\end{array}$ & $\begin{array}{c}-2.4406 \\
-11.9690^{* 2)}\end{array}$ \\
\hline
\end{tabular}

1) A $\left(^{*}\right)$ indicates significance at the 0.05 level.

2) Second difference.

List of used variables and their specification (1992:Q1 - 1999:Q1):

FORDEMAND - weighted average of imports of goods of eight largest Slovenian trading partners in USD (Germany, France, Italy, Austria, the Netherlands, Switzerland, the United 


\begin{tabular}{|c|c|}
\hline IMD - & $\begin{array}{l}\text { imports of goods in USD (manufacturing-total), constant exchange rates } \\
(1995=100) \text {; CIF-type valuation; }\end{array}$ \\
\hline IMDA - & $\begin{array}{l}\text { imports of goods in USD (manufacture of food products, beverages and tobacco), } \\
\text { constant exchange rates }(1995=100) \text {; CIF-type valuation; }\end{array}$ \\
\hline IMDB - & $\begin{array}{l}\text { imports of goods in USD (manufacture of textiles and textile products), constant } \\
\text { exchange rates }(1995=100) \text {; CIF-type valuation; }\end{array}$ \\
\hline IMDC - & $\begin{array}{l}\text { imports of goods in USD (manufacture of leather and leather products), constant } \\
\text { exchange rates }(1995=100) \text {; CIF-type valuation; }\end{array}$ \\
\hline IMDD - & $\begin{array}{l}\text { imports of goods in USD (manufacture of wood and wood products, except } \\
\text { furniture), constant exchange rates }(1995=100) \text {; ClF-type valuation; }\end{array}$ \\
\hline IMDE - & $\begin{array}{l}\text { imports of goods in USD (manufacture of pulp, paper and paper products; } \\
\text { publishing and printing), constant exchange rates }(1995=100) \text {; CIF-type } \\
\text { valuation; }\end{array}$ \\
\hline IMDF - & $\begin{array}{l}\text { imports of goods in USD (manufacture of coke, refined petroleum products and } \\
\text { nuclear fuel), constant exchange rates }(1995=100) \text {; CIF-type valuation; }\end{array}$ \\
\hline IMDG - & $\begin{array}{l}\text { imports of goods in USD (manufacture of chemicals, chemical products and man- } \\
\text { made fibres), constant exchange rates }(1995=100) \text {; CIF-type valuation; }\end{array}$ \\
\hline IMDH - & $\begin{array}{l}\text { imports of goods in USD (manufacture of rubber and plastic products), constant } \\
\text { exchange rates }(1995=100) \text {; CIF-type valuation; }\end{array}$ \\
\hline IMDI - & $\begin{array}{l}\text { imports of goods in USD (manufacture of other non-metallic mineral products), } \\
\text { constant exchange rates }(1995=100) \text {; CIF-type valuation; }\end{array}$ \\
\hline IMDJ - & $\begin{array}{l}\text { imports of goods in USD (manufacture of basic metals and fabricated metal } \\
\text { products), constant exchange rates }(1995=100) \text {; CIF-type valuation; }\end{array}$ \\
\hline IMDK - & $\begin{array}{l}\text { imports of goods in USD (manufacture of machinery and equipment), constant } \\
\text { exchange rates }(1995=100) \text {; CIF-type valuation; }\end{array}$ \\
\hline IMDL - & $\begin{array}{l}\text { imports of goods in USD (manufacture of electrical and optical equipment), } \\
\text { constant exchange rates }(1995=100) \text {; CIF-type valuation; }\end{array}$ \\
\hline IMDM - & $\begin{array}{l}\text { imports of goods in USD (manufacture of transport equipment), constant exchange } \\
\text { rates }(1995=100) \text {; CIF-type valuation; }\end{array}$ \\
\hline IMDN - & $\begin{array}{l}\text { imports of goods in USD (manufacture of furniture n.e.c.), constant exchange } \\
\text { rates }(1995=100) \text {; CIF-type valuation. }\end{array}$ \\
\hline
\end{tabular}

Using the conditional causality model on the sectoral data (see Table 12), we are able to make the following judgments.

Considering the total manufacturing only, the causality between exports and industrial production is bi-directional. Because domestic exporters strongly adjust the pace of their production to the dynamics of foreign orders, either through increase in production to meet the accelerating foreign demand (in such case production in manufacturing stimulates exports) or through reduction, selling of stocks of fabricated products, made or piled up in phases of weak external demand (in such case exports drive domestic production), the exports-production link is bi-directional. On the other hand, domestic production requires sufficient imports and the latter is possible only with adequate export supply.

The bi-directional causality between exports and GDP (industrial production) is a prevailing pattern not just in aggregate data set (total manufacturing), but at the sectoral level as well. Among 13 manufacturing sectors where some type of causality has been found, 7 of them were marked with such bi-directional link. Out of the 6 biggest exporters ${ }^{4)}$ (manufacture of textiles and textile products, manufacture of

4) In terms of fraction of individual sector's exports in total exports and in terms of fraction of individual sector's exports in exports of total manufacturing. These exporting sectors also generate more than 50 per cent of their operating revenues in foreign markets. 
Table 12

Results of Conditional Granger-Sims Causality Test by Sectors of NACE (Variables: Sectoral Exports-DEX, Sectoral Industrial Production-DIND) ${ }^{1)}{ }^{2)}$

\begin{tabular}{|c|c|c|c|c|c|c|}
\hline & \multicolumn{3}{|c|}{ DIND $\rightarrow$ DEX } & \multicolumn{3}{|c|}{ DEX $\rightarrow$ DIND } \\
\hline & $\begin{array}{l}\text { Optimal } \\
\text { Lags }\end{array}$ & F-statistics & Serial(1) & $\begin{array}{l}\text { Optimal } \\
\text { Lags }\end{array}$ & F-statistics & Serial(1) \\
\hline D & $k=2 ; l=2$ & $(2,17) ; 10.669^{* * *}$ & $\begin{array}{c}F(1,16)=10.650^{* * *} ; \\
F(1,15)=2.307\end{array}$ & $m=4 ; n=1$ & $(1,15) ; 29.526^{* * *}$ & $F(1,14)=0.908$ \\
\hline DA & $k=0 ; l=1$ & $(1,23) ; 4.024^{*}$ & $\begin{array}{c}F(1,22)=9.491^{* * *} \\
F(1,21)=1.832\end{array}$ & $m=1 ; n=2$ & $(2,19) ; 1.626$ & $F(1,18)=0.277$ \\
\hline DB & $k=0 ; l=1$ & $(1,23) ; 4.369^{* *}$ & $F(1,22)=1.674$ & $m=3 ; n=3$ & $(3,13) ; 7.122^{* * *}$ & $F(1,12)=1.049$ \\
\hline DC & $k=4 ; l=4$ & $(4,9) ; 2.769^{\star}$ & $F(1,8)=0.904$ & $m=0 ; n=4$ & $\begin{array}{l}\operatorname{FPE}(0,0)<\operatorname{FPE}(0,4) \text { : } \\
\text { one dimensional relation }\end{array}$ & - \\
\hline $\mathrm{DD}$ & $k=0 ; l=1$ & $\begin{array}{l}\operatorname{FPE}(0,0)<\operatorname{FPE}(0,1) \text { : } \\
\text { one dimensional relation }\end{array}$ & - & $m=4 ; n=6$ & $(6,5) ; 8.406^{* *}$ & $F(1,4)=1.113$ \\
\hline$D E$ & $k=0 ; l=5$ & $(5,14) ; 3.711^{* *}$ & $\begin{array}{c}F(1,13)=7.864^{* *} \\
F(1,12)=1.118\end{array}$ & $m=0 ; n=2$ & $(2,20) ; 1.545$ & $F(1,19)=2.323$ \\
\hline DF & $k=0 ; 1=3$ & $(3,19) ; 19.408^{\star \star *}$ & $F(1,18)=0.644$ & $m=5 ; n=4$ & $(4,7) ; 5.460^{\star *}$ & $F(1,6)=0.095$ \\
\hline$D G$ & $k=5 ; l=5$ & $(5,4) ; 8.905^{\star *}$ & $F(1,3)=0.258$ & $m=5 ; n=1$ & $(1,13) ; 8.355^{\star *}$ & $F(1,12)=0.015$ \\
\hline $\mathrm{DH}$ & $k=4 ; l=3$ & $(3,11) ; 11.847^{* \star *}$ & $F(1,10)=1.255$ & $m=5 ; n=6$ & $(6,3) ; 60.893^{* * *}$ & $F(1,2)=0.019$ \\
\hline $\mathrm{DI}$ & $k=0 ; l=1$ & $(1,23) ; 0.054$ & $F(1,22)=1.087$ & $m=0 ; n=1$ & $(1,22) ; 5.154^{* *}$ & $F(1,21)=1.974$ \\
\hline DJ & $k=0 ; l=4$ & $(4,16) ; 6.127^{\star \star *}$ & $F(1,15)=2.167$ & $m=2 ; n=1$ & $(1,19) ; 20.474^{* * *}$ & $F(1,18)=0.002$ \\
\hline DK & $k=4 ; l=4$ & $(4,9) ; 12.724^{* \star *}$ & $F(1,8)=0.254$ & $m=1 ; n=4$ & $(4,15) ; 3.115^{\star *}$ & $F(1,14)=0.008$ \\
\hline $\mathrm{DL}$ & $k=4 ; l=1$ & $\begin{array}{l}\mathrm{FPE}(4,0)<\operatorname{FPE}(4,1) \text { : } \\
\text { one dimensional relation }\end{array}$ & - & $m=5 ; n=3$ & $(3,9) ; 3.839^{*}$ & $F(1,8)=1.298$ \\
\hline $\mathrm{DM}$ & $k=3 ; l=1$ & $(1,17) ; 9.562^{* \star \star}$ & $\begin{array}{c}F(1,16)=5.889^{* *} \\
F(1,15)=0.861\end{array}$ & $m=5 ; n=6$ & $(6,2) ; 19.340^{* *}$ & $F(1,1)=0.014$ \\
\hline DN & $k=4 ; l=1$ & $\begin{array}{l}\operatorname{FPE}(4,0)<\operatorname{FPE}(4,1) \text { : } \\
\text { one dimensional relation }\end{array}$ & - & $m=1 ; n=1$ & $\begin{array}{l}\operatorname{FPE}(1,0)<\operatorname{FPE}(1,1) \text { : } \\
\text { one dimensional relation }\end{array}$ & - \\
\hline
\end{tabular}

1) The letter $D$ before the variables represents the first difference form. Numbers in parentheses are degrees of freedom. $A\left({ }^{*}\right),\left({ }^{* *}\right)$ or $\left({ }^{* \star *}\right)$ indicate significance at the $10 \%, 5 \%$ or $1 \%$ level, respectively.

2) D-Manufacturing (Total); DA-Manufacture of food products, beverages and tobacco; DB-Manufacture of textiles and textile products; DC-Manufacture of leather and leather products; DD-Manufacture of wood and wood products, except furniture; DE-Manufacture of pulp, paper and paper products, publishing and printing; DF-Manufacture of coke, refined petroleum products and nuclear fuel; DG-Manufacture of chemicals, chemical products and man-made fibres; DH-Manufacture of rubber and plastic products; DI-Manufacture of other non-metallic mineral products; DJ-Manufacture of basic metals and fabricated metal products; DK-Manufacture of machinery and equipment; DL-Manufacture of electrical and optical equipment; DM-Manufacture of transport equipment; DN-Manufacture of furniture n.e.c.

chemicals and chemical products, manufacture of basic metals and fabricated metal products, manufacture of machinery and equipment, manufacture of electrical and optical equipment, manufacture of transport equipment), only in manufacture of electrical and optical equipment no evidence could be found in the bi-directional causality between exports and domestic production. Beside in the latter, the hypothesis on export-induced production is confirmed also in manufacture of wood and wood products and in manufacture of other non-metallic mineral products. In the 
remaining three sectors (manufacture of food products, beverages and tobacco, manufacture of leather and leather products, and manufacture of pulp, paper and paper products), sectoral production causes exports. Two conclusions offer the sectoral causality links. First, the prevailing export orientation of individual sector does not unequivocally imply the existence of export generated production; the quoted 5 most export oriented manufacturing industries exhibit bi-directional causality between export and production variables. Behind the two-way causality found in these sectors is the mutual working of two factors: export flows finance the sectors' import demand and imports fuel through domestic production the sectoral export supply. Second, the causality running from production towards exports is valid in sectors, which activity is highly dependent on domestic demand (sector DA, DC and $\mathrm{DE}$ ) - the causality pattern is consistent with the suppositions derived from the product cycle theory.

\section{Conclusion}

Slovenia represents an interesting application for investigating the nature of causality, given its status as a small open economy and the growth path that the Slovenian manufacturing and trade flows have followed in the period of integral economic transformation. Unlike other countries in transition, Slovenia's output development and its trade flows have largely been in tandem since the beginning of country's transition towards a well performing market economy.

In spite of the fact that the export-output relation embodies a long term movement, the aggregate analysis of a short time period by resorting to standard estimation practice suggested, in three out of four observed cases, the conclusion that exports and economic growth exhibit bi-directional causality. Such outcome is fully in accordance with the empirically rejected hypothesis of exogeneity of exports in Slovenia (see Bekő, 2000a). The bi-directional causality in export-output link can be separated in two channels (for additional empirical evidence, see Bekő, 2000b): growing GDP induces imports and creates possibilities for export expansion and exports provide foreign exchange to pay for the import content of remaining components of final demand - consumption, investment and government expenditure. Bidirectionality reflects mainly the growing importance of intra-industry trade, high geographical concentration of Slovenian foreign trade, which intensifies the frequence of export-import flows, and the import requirements of domestic exports (high fraction of import of intermediate goods used in domestic production) (for the empirical assessment of individual factors, see Strojan, Kotar, 1998). In accordance with the causality pattern in aggregate data two-way causalities between export and production variables most often appeared also at the level of sectoral flows. Among 13 manufacturing sectors where some type of causality has been found, 7 of them were marked with bi-directional link. It is also worth noting that all the most export oriented manufacturing industries exhibit such bi-directional causality pattern.

The evidenced bi-directional causality of export-output relation for Slovenia suggest that any characterization of a small country's growth as export-driven may be at least perfunctory. As the results imply, there are no trade-offs between whether to pursue a growth strategy of structural reforms for internal competitiveness with the goal of higher domestic growth and afterwards an increasing exports, or to apply trade policy for improving the international competitiveness and enabling the economy a quick response to foreign demand. Since independence, Slovenia has progressively introduced trade policy measures to liberalize its foreign trade regime. This trade policy with the main objective of enabling exporters to have free access to the international market for whatever purchases, including raw materials, 
capital goods and technology,5) has to be, in the current phase of increasing legal and economic approximation to the EU-club, complemented with policy actions that intend to encourage new entries of foreign companies on domestic market and to facilitate the competition pressures arising from enhancement of imports and FDI. The recorded export-oriented growth must also be accompanied by appropriate industrial policy, where special care should be devoted to the promotion of technological development, stimulation of further enterprise creation and to the necessary upgrade of Slovenia's comparative advantages through FDI.

It is to be expected that these policy measures together with the continuing economic convergence of the Slovenian economy with the EU will additionally strengthen the bi-directional causality between export flows and domestic economic activity found in the present study. At the academic level, however, the controversy remains whether it is possible to explain the existence of bi-directional causality between exports and economic growth in (other) Central and Eastern European economies with the attributes of new trade theories, or perhaps other theoretical explications should be developed for these countries.

References

Afxentiou, P. C., Serletis, A. (1991), "Exports and GNP Causality in the Industrial Countries." Kyklos, 44, pp. 167-179.

Ahmad, J., Harnhirun, S. (1995), "Unit Roots and Cointegration in Estimating Causality between Exports and Economic Growth: Empirical Evidence from the ASEAN Countries." Economics Letters, 49, pp. 329-334.

Akaike, H. (1970), "Statistical Predictor Identification." Annals of the Institute of Statistical Mathematics, 22, pp. 203-217.

Bank of Slovenia. Internal database (Ljubljana).

Bank of Slovenia. Monthly Bulletin, various issues, Ljubljana.

Beckerman, W. H. (1962), "Projecting Europe's Growth." Economic Journal, 288, pp. 912-925.

Bekő, J. (1999), "Analysis of Import Demand and Export Supply in Slovenia - Empirical Regularities and Stylized Facts." Eastern European Economics, 37, pp. 39-90.

(2000), "Exports and Economic Growth: Some Stylized Facts and Preliminary Results about Exogeneity of Exports in Slovenia" (in Slovenian). IB revija, 34, pp. 24-43(a).

(2000), "Reconsideration of the Growth Pattern of a Small Economy: Exports and Economic Growth in Slovenia." Maribor. Mimeo(b).

Bole, V. (1994), "Capital Inflow over Households and the Economic Performance" (in Slovenian). Gospodarska gibanja, 10, pp. 23-42.

Charemza, W. W., Deadman, D. F. (1997), New Directions in Econometric Practice. Cheltenham: Edward Elgar.

Coe, D. T., Helpman, E. (1995), “International R\&D Spillovers.” European Economic Review, 5, pp. 859-887.

Dickey, D. A., Hasza, D. P., Fuller, W. A. (1984), "Testing for Unit Roots in Seasonal Time Series." Journal of the American Statistical Association, 79, pp. 355-367.

Engle, R. F., Granger, C. W. J. (1991), "Co-integration and Error Correction: Representation, Estimation, and Testing," in Engle, R. F., Granger, C. W. J., eds., Long-run Economic Relationships, Readings in Cointegration. Oxford: Oxford University Press.

Giles, D. E. A., Giles, J. A., McCann, E. (1993), "Causality, Unit Roots and Export-led Growth: The New Zealand Experience." The Journal of International Trade \& Economic Development, 2, pp. 195218.

5) Coe and Helpman (1995), and Keller (1997, 1999) concisely demonstrated why the creation of competitive export sector of a small economy has to be searched predominantly in the appropriate composition of its imports. 
Giles, J. A., Williams, C. L. (2000), "Export-led Growth: A Survey of the Empirical Literature and Some Non-causality Results. Part 1." The Journal of International Trade \& Economic Development, (9) 3, pp. 261-337(a).

(2000), "Export-led Growth: A Survey of the Empirical Literature and Some Non-causality Results. Part 2." The Journal of International Trade \& Economic Development, (9) 4, pp. 445-470(b).

Granger, C. W. J. (1988), "Some Recent Developments in a Concept of Causality." Journal of Econometrics, 39, pp. 199-211.

Greenaway, D., Sapsford, D. (1994), “Exports, Growth, and Liberalization: An Evaluation.” Journal of Policy Modelling, 16, pp. 165-186.

Hirsch, S. (1967), Location of Industry and International Competitiveness. London: Oxford University Press.

Hsiao, C. (1979), "Autoregressive Modelling of Canadian Money and Income Data." Journal of the American Statistical Association, 74, pp. 553-560.

(1981), "Autoregressive Modelling and Money-Income Causality Detection." Journal of Monetary Economics, 7, pp. 85-106.

Slovenian Economic Mirror. Ljubljana, Institute of Macroeconomic Analysis and Development, various issues.

Johansen, S. (1991), "Estimation and Hypothesis Testing of Cointegration Vectors in Gaussian Vector Autoregressive Models." Econometrica, 59, pp. 1551-1580.

Jones, J. D., Joulfaian, D. (1991), "Federal Government Expenditures and Revenues in the Early Years of the American Republic: Evidence from 1792 to 1860." Journal of Macroeconomics, 13, pp. 133-155.

Keller, W. (1997), "Are International R\&D Spillovers Trade-related? Analyzing Spillovers among Randomly Matched Trade Partners." Cambridge, MA, NBER Working Paper No. 6065.

(1999), "How Trade Patterns and Technology Flows Affect Productivity Growth." Cambridge, MA, NBER Working Paper No. 6990.

Krugman, P. R. (1979), "Increasing Returns, Monopolistic Competition, and International Trade." Journal of International Economics, 4, pp. 469-479.

(1980), "Scale Economies, Product Differentiation, and the Pattern of Trade." The

American Economic Review, 5, pp. 950-959.

Marin, D. (1992), "Is Export-led Growth Hypothesis Valid for Industrialized Countries?" The Review of Economics and Statistics, 74, pp. 678-688.

Markusen, A. R. (1985), Profit Cycles, Oligopoly, and Regional Development. Cambridge, MA: MIT Press.

McCombie, J. S. L., Thirlwall, A. P. (1994), Economic Growth and the Balance-of-Payments Constraint. London: St. Martin's Press.

Mrak, M., Rojec, M., Potočnik, J. (2002), "The Transition Process in Slovenia: Transformation to an EU-compatible Economy." Journal of International Relations and Development, 1, pp. 37-62.

Osborn, D. R., Chui, A. P. L., Smith, J. P., Birchenhall, C. R. (1988), "Seasonality and the Order of Integration for Consumption." Oxford Bulletin of Economics and Statistics, 50, pp. 361-377.

Pomponio, X. Z. (1996), "A Causality Analysis of Growth and Export Performance." Atlantic Economic Journal, 24, pp. 168-176.

Riezman, R. G., Whiteman, C. H., Summers, P. M. (1996), "The Engine of Growth or its Handmaiden? A Time-series Assessment of Export-led Growth," in Durlauf, S., Helliwell, J. F., Raj, B., eds., Longrun Economic Growth. Heidelberg: Springer-Verlag.

Sargent, T. J., Wallace, N. (1973), "Rational Expectations and the Dynamics of Hyperinflation." International Economic Review, 14, pp. 328-350.

Sims, C. A. (1972), "Money, Income, and Causality." The American Economic Review, 62, pp. 540-552. Statistical Yearbook of the Republic of Slovenia. Ljubljana, Statistical Office of the Republic of Slovenia, various issues.

Strojan, A., Kotar, T. (1998), "Concentration of Commodity Trade and the Importance of Intra-industry Trade" (in Slovenian). Prikazi in analize, 1, pp. 40-58.

Thornton, D. L., Batten, D. S. (1985), "Lag-length Selection and Tests of Granger Causality between Money and Income." Journal of Money, Credit, and Banking, 17, pp. 164-178.

Vernon, R. (1966), "International Investment and International Trade in the Product Cycle." Quarterly Journal of Economics, 2, pp. 190-207. 